\section{Occurrence of the Red Kite Milvus milvus IN SLOVENIA}

\section{Pojavljanje rjavega škarnika Milvus milvus v Sloveniji}

\section{DeJAN BORDJAN ${ }^{1}$}

1 Oddelek za gozdarstvo in obnovljive gozdne vire, Biotehniška fakulteta, Univerza v Ljubljani, Večna pot 83, SI-1000 Ljubljana, Slovenia

The Red Kite is a bird of prey that breeds almost exclusively in Europe (BIRDLIFE INTERNATIONAL 2004). Globally, as well as in Europe, it has the status of a near threatened species (BIRDLIFE INTERNATIONAL 2015). The population as a whole has been in decline for almost three generations (BirdLife International 2004, 2015). Western and southern European populations are resident, but most birds in the northeast are migratory (BIRDLIFE INTERNATIONAL 2017).

Although the Red Kite was present in Slovenia in historical times, most authors agree that it is a rare species with only few observations and specimens in museum collections (SCHULz 1890, SCHIAvUzzI 1883, REISER 1925). It was assumed to be a breeder (GEISTER 1995) and an extremely rare winter visitor (Sovinc 1994). In the early 1990s it was listed as a rare bird in the breeding and wintering periods by the National Rarities Committee (Komisija ZA REDKOSTI 1993). Although it occurs more often during migration, it was listed as a rare visitor in overviews of birds on Ljubljansko barje (TOME et al. 2005), at Medvedce reservoir (BORDJAN \& BožIČ 2009), at Lake Cerknica (BordJAN 2012B), at Vrbje fishpond (GAMSER \& NovaK 2013), in Ljubljana and surrounding areas (TOME et al. 2013) and at Sečovlje saltpans (ŠKORNIK 2012). An increased number of sightings was reported only for the Medvedce reservoir (Bordjan 2012A). Due to the low number of sightings at individual sites, the phenology of the species in Slovenia has so far been missing, nor has there ever been an overview of the species' occurrence.

Data for the present review were collected from the journal Acrocephalus, from the online database
Atlas ptic NOAGS (http://http://atlas.ptice.si/ atlas), from online birding groups, online photo galleries and directly from observers.

Between 1977 and January 2017, 117 records of 121 individuals were made. 113 of the observations concerning single individuals. Two individuals were observed together only four times. Most observations concerned migratory birds and only few records individuals present for more than one day. In 2009 and 2010, at least one individual was present at the Vodovnik farmhouse near Topolšica from April till October and November, respectively (I. JELENKo pers. comm.). Despite being present during the entire breeding season, breeding was not confirmed. Longer stays were also recorded at Savska loka near Dolsko (Trontelj 2008), in the SE part of Ljubljansko barje (ŠERE 2015, ATLAS PTIC 2017) and at Lake Šoštanj (ČELIK 1993).

The number of annual records has been rising from 1980 onwards (Figure 1; $\mathrm{R}_{\text {Spearman }}$ : 0.71; $\mathrm{p}<$ $0.001 ; \mathrm{df}=36)$. In the $1980 \mathrm{~s}$, on average less than one Red Kite was observed per year, 1.1 in the $1990 \mathrm{~s}$ and 3.0, between 2000 and 2009, while, after 2009, 9 Red Kites were observed each year. Red Kites were observed in all months of the year with the fewest observations during the summer months (Figure 2). With the exception of the individual near Topolščica, only two observations were made between 20 Jun and 30 Aug. Fewer observations were recorded during the winter as well. In December and January, altogether six birds were observed (Figure 2). The first migratory Red Kites were recorded at the beginning of February. The number of observations rose until the start of April and eventually dropped towards its end (Figure 2). There is a second peak in May. During the autumn migration, the first Red Kites were observed at the end of August. The number of observations rose through September peaking in the beginning of October (Figure 2). The last autumn observation was made at Ljubljansko barje on 12 Nov (Tome et al. 2005).

Red Kites were sighted over much of the country, from Goričko and Pomurje in the east to Breginjski Stol and Sečovlje saltpans in the west (Figure 3). Observations are concentrated in the areas of prolonged bird censuses, for example: Medvedce reservoir (27 observations), 


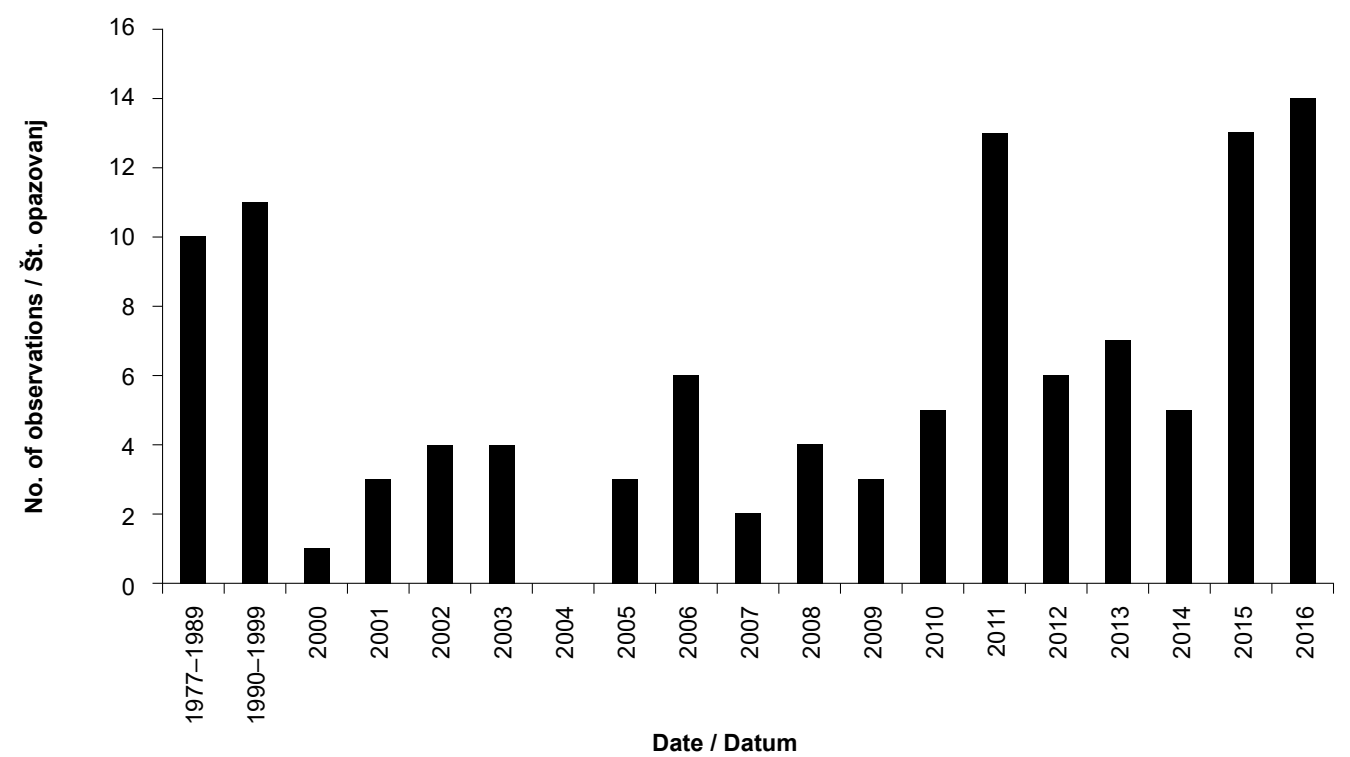

Figure 1: Annual observations of Red Kite Milvus milvus in Slovenia between 1977 and 2016

Slika 1: Letno število opazovanj rjavih škarnikov Milvus milvus v Sloveniji med letoma 1977 in 2016

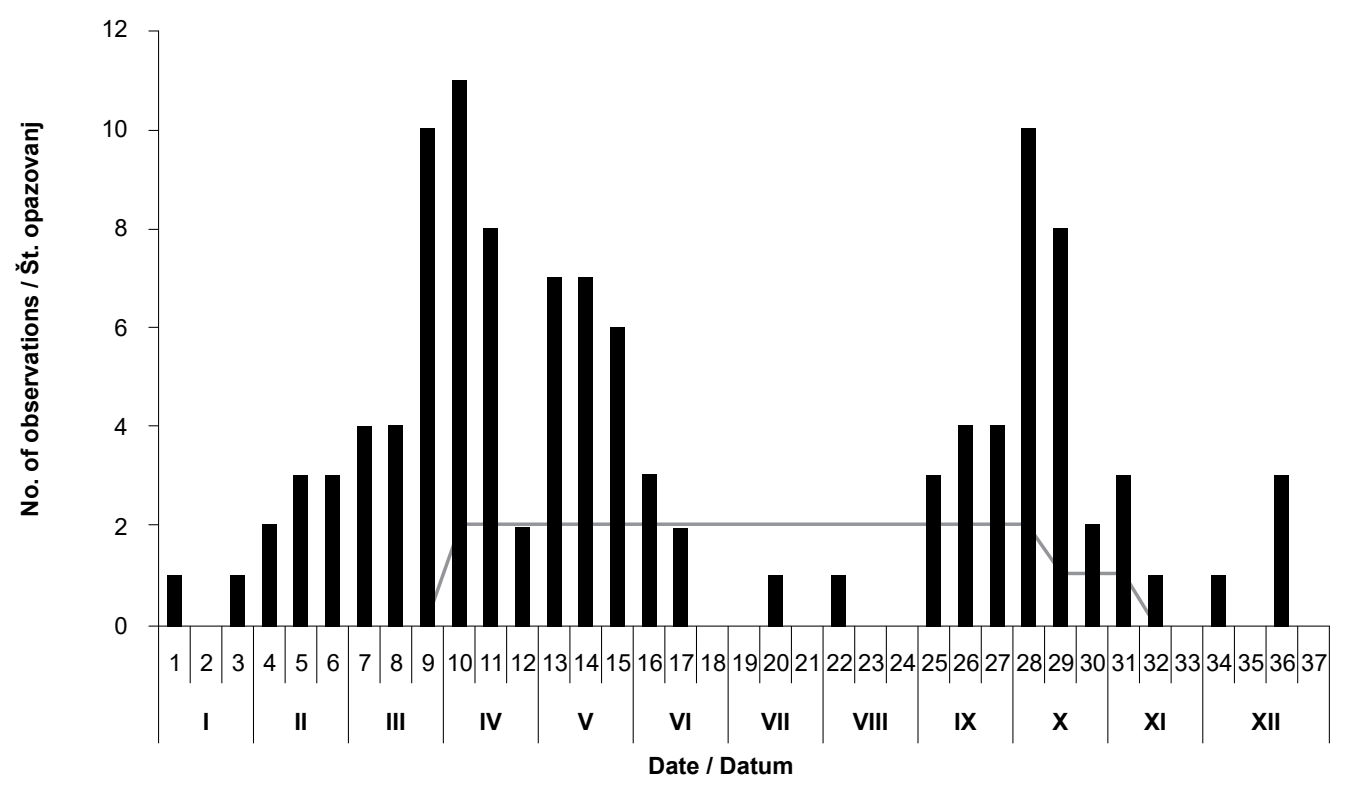

Figure 2: Phenology of Red Kite Milvus milvus observations in Slovenia, with grey line indicating one individual observed at the Vodovnik farmhouse near Topolšica in 2009 and 2010

Slika 2: Fenologija opazovanj rjavih škarnikov Milvus milvus v Sloveniji. Siva črta ponazarja zadrževanje enega osebka pri kmetiji Vodovnik pri Topolšici v letih 2009 in 2010. 


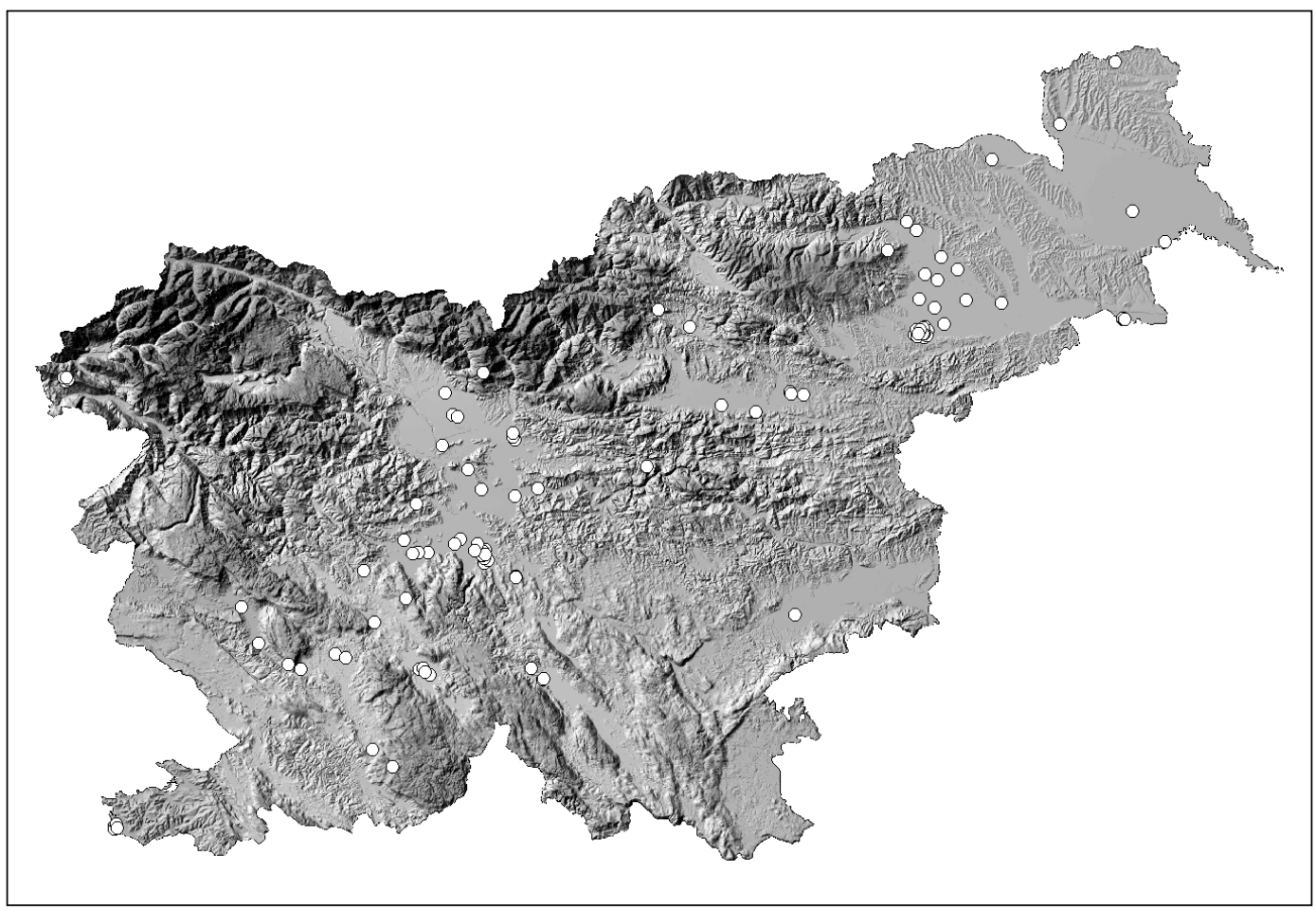

Figure 3: Distribution of Red Kite Milvus milvus observations in Slovenia

Slika 3: Prostorska razširjenost opazovanj rjavih škarnikov Milvus milvus v Sloveniji

Ljubljansko barje (15), Sečovlje saltpans (4), Lake Cerknica (4), Ormož lagoons (3), and also in the areas of higher birdwatching concentrations, e. g. Ljubljana basin (11) and Dravsko polje (9). Data are absent from mountainous areas in the north and northwest and forested areas in the south and southeast (Figure 3). Most of the observations were made in the lowlands. The highest altitude observation concerns an individual recorded on Mt Krvavec at 1,740 m a.s.l. (ŠERE 2011). Apart from that, Red Kite was observed above $1,000 \mathrm{~m}$ a.s.l. also at Breginjski Stol (BožIč 2004, DENAC 2010) and at the top of Mt Pohorje above Maribor (BožIČ 1991).

Although the Red Kite population as a whole is in decline, the populations in Poland, Sweden (BirdLife InTERnational 2015) as well as Czech Republic (KNOTT et al. 2009) are increasing. These migratory populations mostly migrate towards the southwest (KNOTT et al. 2009). Along with a much better data-gathering tool (MiHELIČ 2016), the increases in countries to the north and northeast of Slovenia may explain the substantial increase in the number of observations. Migration periods based on Slovenian data match arrivals and departures from breeding areas (URCUN \& BRIED 1998, BIRDLIFE INTERNATIONAL 2015). Since the return to breeding area mostly lasts till the end of April (BIRDLife InTERnATIONAL 2017), birds sighted in May are probably nonbreeding individuals. The small number of winter observations is surprising since there is a tendency for birds in central Europe to overwinter, e. g. in Moravia (Czech Republic) (KNOTT et al. 2009). On the other hand there is a slight trend towards more winter observations of Red Kite during the winter in Slovenia. Half (3) of all observations were made in the past six years, and the last two in the past two years, but this might only be a coincidence. Higher density of 
observations in certain areas could be related to the higher observation effort. On the other hand, their absence from higher altitudes and extensive forested areas could also be explained by by the tendency of the species to occupy open areas at low to middle at low to middle altitudes (KNOTT et al. 2009). Since Red Kites occur mostly in the altitude belt $0-800 \mathrm{~m}$ a.s.l. and rarely to 2,500 $\mathrm{m}$ a.s.l. (BIRDLIFE INTERNATIONAL 2015), the fact of only three sightings above $1,000 \mathrm{~m}$ a.s.l. in Slovenia comes as no surprise.

\section{Abstract}

The Red Kite Milvus milvus breeds alomost exclusively in Europe, its population is in decline. In the past, it was regarded as a rare migrant in Slovenia. In the 1990s it was classified as a possible breeder, extremely rare winter guest with more observations during migration. Between 1977 and January 2017117 records of 121 individuals were gathered. Most (113) involved single birds on migration. Exceptionally, birds were present for a longer period - a single record of a summering bird is known. Since 1980 the number of birds per year increased from 1 to $1.1,3$ and 9 after 2009. Possible reasons are increased awareness and population increases to the north and northeast of Slovenia. Red Kites were observed throughout the year with the lowest numbers during summer and winter, which surprising, because the species is increasingly common during winter in central Europe. Migration of Red Kites in Slovenia begins in February with a peak in early April and May and between August and mid-November with a peak in early in October. The migration period coincides with arrivals and departures from breeding grounds. Red Kites have been observed all across the country, with more observations at well-watched sites. Birds were observed between sea level and $1740 \mathrm{~m}$ a.s.l. with only a handful of observations above $1000 \mathrm{~m}$ a.s.l.

Key words: Red Kite, Milvus milvus, phenology, migration, altitudinal distribution

\section{Povzetek}

Rjavi škarnik Milvus milvus gnezdi skoraj izključno v Evropi in njegova populacija upada.
V preteklosti je bil redek preletnik. V 90. letih 20. stoletja je imel status možnega gnezdilca in izredno redkega prezimovalca $z$ več opazovanji med selitvijo. Zbrano je bilo 117 podatkov o 121 osebkih med letom 1977 in januarjem 2017. Večinoma (113) so bili opazovani posamezni osebki na selitvi. Le izjemoma so se osebki zadrževali dalj časa in zbrana sta samo dva podatka o letovanju enega osebka v dveh letih na isti lokaciji. Število opazovanj se je od leta 1980 v posameznih desetletjih dvigovalo od manj kot 1 osebek do 1,1, 3 in 9 osebkov na leto po letu 2009. Možni razlogi za ta občutni dvig opazovanj so boljše orodje za zbiranje podatkov ter dvigi populacij severno in severovzhodno od Slovenije. Rjavi škarniki so bili opazovani v vseh mesecih leta $\mathrm{z}$ najnižjim številom opazovanj v poletnih in zimskih mesecih. Slednje je presenetljivo, saj vedno več osebkov prezimuje v srednji Evropi. Selitev rjavih škarnikov v Sloveniji traja med začetkom februarja $\mathrm{z}$ viškom začetek aprila in v maju ter med koncem avgusta in sredino novembra $\mathrm{z}$ viškom $\mathrm{v}$ začetku oktobra. Selitveno obdobje se ujema s prihodi in odhodi z gnezdišč. Rjavi škarnik je bil opazovan po večjem delu države $z$ več opazovanji na območjih večje ornitološke pozornosti. Opažen je bil od obale do višine $1740 \mathrm{~m} \mathrm{n}$. v., z glavnino opazovanj po nižinah in le s peščico nad $1000 \mathrm{~m} \mathrm{n}$. v.

Ključne besede: rjavi škarnik, Milvus milvus, fenologija, selitev, višinska razširjenost

\section{References}

BIRDLIFE INTERNATIONAL (2004): Birds in Europe: population estimates, trends and conservation status. BirdLife Conservation Series No. 12. - BirdLife International, Cambridge.

BIRDLIFE INTERNATIONAL (2015): European Red list of Birds. Office for official publications of the European Communities.

BirdLife InTERnational (2017): Species factsheet: Milvus milvus. - (http://www.birdlife.org; 10/10/2017).

Bordjan D. (2012A): Rjavi škarnik Milvus milvus. Acrocephalus 32 (150/151): 218.

BordjAN D. (2012B): Vodne ptice in ujede Cerkniškega polja (južna Slovenija) v letih 2007 in 2008, s pregledom zanimivejših opazovanj do konca leta 2010. - Acrocephalus 33 (152/153): 25-104.

Bordjan D., Božıč L. (2009): Pojavljanje vodnih ptic in ujed na območju vodnega zadrževalnika Medvedce 
(Dravsko polje, SV Slovenija) v obdobju 20022008. - Acrocephalus 30 (141/142/143): 55-163.

Božıč L. (1991): Rjavi škarnik Milvus milvus. Acrocephalus 12 (49): 153-154.

Božıč L. (2004): Rjavi škarnik Milvus milvus. Acrocephalus 25 (123): 224-225.

ČELIK T. (1993): Rjavi škarnik Milvus milvus. Acrocephalus 14(60): 161.

DenaC K. (2010): Census of migrating raptors at Breginjski Stol (NW Slovenia) - the first confirmed bottleneck site in Slovenia. - Acrocephalus 31 (145/146): 77-92.

Gamser M., NovaK J. (2013). Pojavljanje vodnih ptic in ujed na širšem območju ribnika Vrbje pri Žalcu. Raziskovalna naloga. (http://www.prvagim. si/modules/uploader/uploads/system_menu/ files_system/pojavljanje-vodnih-ptic-in-ujed.pdf), $10 / 02 / 2017$.

Geister I. (1995): Ornitološki atlas Slovenije. - DZS, Ljubljana.

Knott J., Newbery P., Barov B. (2009): Action plan for the Red Kite Milvus milvus in the European Union. - http://ec.europa.eu/environment/nature/ conservation/wildbirds/action_plans/docs/milvus_ milvus.pdf

Komisija ZA REDKoSTI (1993): Seznam redkih vrst ptic Slovenije 1990. - Acrocephalus 14 (58/59): 99-119.

Minelič T. (2016): Spletna beležka kot nov pripomoček favnistike. - Acrocephalus 37 (168/169): 1-3.

Reiser O. (1925): Die Vögel von Marburg an der Drau. Nauturwissenschaftlichen Verein in Steiermark, Graz, 143 p

Schiavuzzi B. (1883): Materiali per un'avtfauna del territorio di Trieste fino a Mortfalcone e deli'Istria. Bollettino della Societa Adriatica Scienze Naturali, 8, 3-78.

Schulz F. (1890): Verzeichnis der bisher in Krain beobachteten Vögel. Laibach.

Sovinc A. (1994): Zimski ornitološki atlas Slovenije. Tehniška založba Slovenije, Ljubljana.

ŠERE D. (2011): Rjavi škarnik Milvus milvus. Acrocephalus 32 (148/149): 90.

ŠERE D. (2015): Rjavi škarnik Milvus milvus. Acrocephalus 36 (166/167): 186.

ŠKORNIK I. (2012): Favnistični in ekološki pregled ptic Sečoveljskih solin. - Soline pridelava soli, Seča.

Tome D., Sovinc A., Trontelj P. (2005): Ptice Ljubljanskega barja. Monografija DOPPS št. 3. Društvo za opazovanje in proučevanje ptic Slovenije, Ljubljana.

Tome D., Vrezec A., Bordjan D. (2013): Ptice Ljubljane in okolice. - Ljubljana, Mestna občina, Oddelek za varstvo okolja.

Trontelj P. (2008): Ptice občine Dol pri Ljubljani. Omerzu S. (ed.): Iz dežele Jurija Vege. - Zbornik Občine Dol pri Ljubljani 1. Dol pri Ljubljani, 2008.
UrCun J.-P., Bried J. (1998): The Autumn Migration of the Red Kite Milvus milvus through the Pyrenees. In: Chancellor R. D., Meyburg B.-U., Ferrero J. J. (eds.): Holarctic Birds of Prey. - Proceedings of an International Conference. Merida \& Berlin: ADENEX \& WWGBP.

Prispelo / Arrived: 21. 2. 2017

Sprejeto / Accepted: 12. 10. 2017 